\title{
PENGARUH PENGETAHUAN ANGGOTA DEWAN TENTANG ANGGARAN TERHADAP PENGAWASAN KEUANGAN DAERAH DENGAN TRANSPARANSI KEBIJAKAN PUBLIK DAN AKUNTABILITAS SEBAGAI VARIABEL MODERATING
}

\author{
(STUDI KASUS PADA DPRK KABUPATEN ACEH UTARA)
}

\author{
Dy Ilham Satria ${ }^{1}$, Debi Narisa ${ }^{2}$ \\ ${ }^{1,2}$ Prodi Akuntansi Fakultas Ekonomi dan Bisnis Universitas Malikussaleh Lhokseumawe \\ dyihamsatria@unimal.ac.id
}

\begin{abstract}
This study aimed to determine the effect of the knowledge of board member about the budget on the supervision of regional finances with the transparency of public policy and accountability as moderating variables. The samples of this study were taken using Census sampling technique in which the entire population used as the sample. Questionnaires were distributed as many as 45 questionnaires and returned 39 questions, then analyzed using Moderated Regression Analysis and the hypothesis were tested using SPSS. The results of this study showed that the knowledge of board members about the budget had a significant positive effect on the supervision of regional finances. The knowledge of board member of budgets with the transparency of public policy as moderating variable influence negatively on the supervision of regional finance. The results of this test indicate that the Transparency of Public Policy weakened the relationship between the knowledge of board members about budgets to the supervision of regional finances. The knowledge of board members about budgets with accountability as a moderating influenced the supervision of regional finances, the results of these tests explained that accountability strengthened the relationship of knowledge of board members on budgets toward the supervision of regional finance. Simultaneous test $(f$-test) indicated that the knowledge of board members about budgets influenced the supervision of regional finance with the transparency of public policy and accountability as moderating variables that can be seen with the value of sig 0,029 that is less than 0,05 so that the hypothesis was accepted.
\end{abstract}

Keywords: LocalFinancial Supervision, Knowledge of Board Members about Budgets, Transparency of Public Policy, Accountability.

\section{PENDAHULUAN}

Secara umum, lembaga legislatif (DPR/DPRD) mempunyai tiga fungsi yaitu: 1) fungsi legislasi (fungsi membuat peraturan perundangundangan), 2) fungsi anggaran (fungsi untuk menyusun anggaran) dan 3) fungsi pengawasan (fungsi untuk mengawasi kinerja eksekutif). Dalam penelitian ini, fungsi dewan dalam pengawasan anggaran mulai dari tahap penyusunan, pelaksanaan hingga pelaporan dan evaluasi anggaran yang dilakukan lembaga legislatif.( Darma dan Hasibuan, 2012).

Pengawasan merupakan hal yang sangat penting dalam setiap pekerjaan, Sebab dengan adanya pengawasan yang baik maka sesuatu pekerjaan akan dapat berjalan lancar dan disertai pengawasan yang baik maka pekerjaan itu akan berhasil dengan baik.
Dalam suatu pengawasan keuangan daerah pasti ada yang mengawasi dan pengawasan, beberapa subjek dalam pengawasan keuangan daerah dalam Pasal 9 ayat (1) Undang-undang No 1 Tahun 2004 tentang Perbendaharaan negara dimana kepala satuan kerja pengelola keuangan daerah adalah bendahara umum daerah yang diberi kewenangan yang terdapat dalam Pasal 9 ayat (2) Undang-undang No 1 Tahun 2004 tentang perbendaharaan negara.

Pengawasan yang dilakukan oleh dewan dipengaruhi oleh faktor internal dan eksternal Suryanto (2015). Faktor internal adalah faktor yang dimiliki oleh dewan yang berpengaruh secara langsung terhadap pengawasan yang dilakukan oleh dewan, salah satunya adalah pengetahuan tentang anggaran. Pengawasan terhadap pelaksanaan pemerintahan yang tepat sangat tergantung pada pengetahuan dan kecakapan anggota DPRD. Pengetahuan yang luas dan mendalam akan 
memberikan kemampuan untuk mengartikulasikan segala kepentingan rakyat serta menentukan cara yang lebih tepat dan efisien. Sedangkan faktor eksternal yang mempengaruhi pengawasan adalah pengaruh dari luar terhadap fungsi pengawasan dan diantaranya adalah kebijakan publik dan akuntabilitas.

Agar anggaran dalam pemerintah dapat daerah berjalan sesuai dengan rencana yang sudah di tentukan maka diperlukan pengawasan yang merata disetiap aspek perencanaan, apakah perencanaan tersebut berjalan secara efesien, efektif dan ekonomis. Berdasarkan Undang-undang No.58 Tahun 2005 tentang Pengelolaan Keuangan Daerah menyatakan bahwa pengawasan atas pelakasanaan APBD dilakukan oleh DPRD. Pengawasan terhadap pengelolaan keuangan daerah sangat penting dilakukan, karena pengawasan merupakan suatu usaha untuk menjamin adanya keserasian antara penyelenggaraan tugas pemerintah di daerah (pusat) dan menjamin kelancaran penyelenggaraan pemerintah secara berdaya guna. Ayu Julianastuti (2013).

Menurut W.N.Dunn

mengungkapkan bahwa kebijakan publik adalah sebuah list pilihan suatu tindakan yang saling terhubung yang disusun oleh sebuah instansi atau pejabat pemerintah antara lain dalam sebuah bidang pertahanan, kesehatan, pendidikan, kesejahteraan, pengendalian kriminalitas, dan sebuah pembangunan perkotaan. Menurut Woll mengungkapkan bahwa Kebijakan publik adalah sejumlah sebuah kegiatan pemerintah dalam memecahkan suatu masalah dalam masyarakat, baik secara langsung atau pun melalui berbagai suatu lembaga yang dipengaruhi sebuah kehidupan masyarakat, dan selanjutnya kebijakan publik yakni sebagai suatu hubungan unit pemerintah dengan sebuah lingkungannya. Dalam pernyataan ini bisa diklasifikasikan sebagai democratic governance, yang mana didalamnya terdapat suatu interaksi negara dengan rakyatnya dalam rangka untuk mengatasi dalam persoalan publik

Dengan adanya kebijakan publik dapat diartikan sebagai pelaksanaan tugas dan kegiatan yang menjamin akses atau kebiasaan setiap orang untuk memperoleh informasi tentang kebijakan, proses pembuatan dan pelaksanaannya, serta hasil yang telah dicapai dapat diakses atau didapat oleh masyarakat dengan baik dan terbuka. Kebijakan publik berarti adanya akses bagi masyarakat untuk dapat mengetahui proses dari anggaran serta kebijakankebijakan yang dibuat oleh pemerintah sehingga dapat diketahui dan diawasi oleh masyarakat pula. Dengan adanya kebijakan publik ini, akan berpengaruh terhadap pengetahuan dewan tentang anggaran dan pengawasan keuangan daerah yang dilakukan oleh anggota dewan. Utami,2013 (Utama, 2015).

\section{TINJAUAN PUSTAKA LANDASAN TEORITIS}

Teori Kegenan menjelaskan mengenai adanya hubungan yang terjadi antara manager dengan pemegang saham. Jenses dan Meckling menjelaskan bahwa hubungan agensi dapat tercipta karena adanya kontrak antara Principal (pemegang saham dan penyedia hutang) dengan agent (manager) untuk melakukan pelayanan kepada pemilik perusahaan (godfrey dalam Hartono 2016). Teori keagenan apabila dihubungkan dengan sektor publik berarti masyarakat berperan sebagai pemberi amanah sekaligus sebagai pemilik (owner) dan pelanggan (customer). Pemerintah daerah dan dewan perwakilan rakyat daerah (DPRD) dengan fungsinya sebagai pemberi pelayanan kepada masyarakat (Civil service) atau dengan kata lain sebagai manajemen.

Dalam organisasi sektor publik, pemerintah daerah berperan sebagai agen dan publik atau masyarakat berperan sebagai prinsipal yang memberikan otoritas kepada DPRD untuk mengawasi kinerja pemerintah daerah. Akuntabilitas menjadi suatu konsekuensi logis adanya hubungan antara agen dan prinsipal. Dari sisi teori keagenan, dapat dinyatakan bahwa pengawasan yang dilakukan oleh legislatif terhadap anggaran yang dilaksanakan oleh eksekutif merupakan suatu mekanisme untuk mengurangi adanya asimetri atau mngurangi ketidakpastian.

\section{Pengawasan Keuangan Daerah}

Secara umum pengawasan dapat dirumuskan sebagai suatu proses kegiatan yang dilakukan secara terus menerus atau berkesinambungan untuk mengamati, memahami, dan menilai setiap pelaksanaan kegiatan tertentu sehingga dapat mencegah atau memperbaiki kesalahan atau penyimpangan yang terjadi (Halim dan Iqbal, 2012:37).

Aspek penting yang harus dipertimbangkan yaitu: 1) Aspek legalitas penerimaan dan pengeluaran daerah bahwa setiap transaksi yang dilakukan harus dapar dilacak otoritas legalnya, 2) Aspek pengelolaan (sterwarship) keuangan daerah secara baik, perlindungan asset fisik dan finansial mencegah terjadinya pemborosan dan salah urus. Untuk ini, perumusan kebijakan, bersama-sama dengan cara dan hasil kebijakan tersebut harus dapat diakses dan dikomunikasikan secara vertikal maupun horizontal dengan baik. Mardiasmo (Wiguna, et.al, (2015).

Menurut Fathoni (2006:30) pengawasan adalah suatu proses untuk menetapkan aparat atau unit bertindak atas nama pimpinan organisasi dan bertugas mengumpulkan segala data dan informasi yang diperlukan oleh pimpinan organisasi untuk menilai kemajuan dan kemunduran dalam pelaksanaan pekerjaan. Menurut Halim (2012:44), pengawasan dilihat dari metodenya terbagi menjadi 2 (dua) yaitu:

1. Pengawasan melekat yang dilaksanakan oleh pimpinan atau atasan langsung suatu 
instansi/unit kerja dalam lingkungan pemerintah daerah terhadap bawahannya.

2. Pengawasan fungsional yang dilakukan oleh aparat pengawasan fungsional APBD yang meliputi BPKP, Itwilprop, ItwilKab/Kota.

Menurut Peraturan Pemerintah Republik Indonesia Nomor 58 Tahun 2005 Tentang Pengelolaan Keuangan daerah dan dalam Bab 4 Penyusunan Rencana APBD dan dalam pasal 29 ialah RPJMD untuk jangka waktu 5 (lima) tahun merupakan penjabaran dari visi, misi, dan program kepala daerah yang penyusunannya berpedoman kepada RPJP Daerah dengan memperhatikan RPJM Nasional dan standar pelayanan minimal yang ditetapkan oleh pemerintah.

Pengawasan keuangan daerah, dalam hal ini adalah pengawasan terhadap angaran keuangan daerah/APBD. Menurut Undang-Undang Nomor 32 Tahun 2004 tentang Pemerintah Daerah Pasal 42 menjelaskan bahwa DPRD mempunyai tugas dan wewenang melaksanakan pengawasan terhadap pelaksanan Perda dan peraturan perundang-undangan lainya, peraturan kepala daerah, APBD, kebijakan pemerintah dalam melaksanakan program pembangunan daerah dan kerjasama internasional di daerah.

Berdasarkan dari Undang-Undang tersebut dapat diambil kesimpulan bahwa pengawasan keuangan daerah dilakukan oleh DPRD yang berfokus kepada pengawasan terhadap pelaksanan APBD. Indikator pengawasan keuangan daerah menurut (Sopanah dan Isa wahyudi 2010) terdiri dari:

$\begin{array}{ll}\text { 1. } & \text { Penyusunan } \\ \text { 2. } & \text { Pengesahan, } \\ \text { 3. } & \text { Pelaksanaan dan } \\ \text { 4. } & \text { Pertanggung jawaban }\end{array}$

\section{Pengaruh Pengetahuan Anggota Dewan Tentang Anggaran Terhadap Keuangan Daerah}

Pengetahuan sebagai kepandaian yaitu segala sesuatu yang diketahui, berkenan dengan sesuatu yang dipelajari. Pengalaman dan pengetahuan yang tinggi akan sangat membantu seseorang dalam memecahkan persoalan yang dihadapinya sesuai dengan kedudukan anggota DPRD sebagai wakil rakyat. (Aditya Dibyo Saputro, 2012)

Jadi, dengan adanya pengetahuan maka anggota dewan akan lebih menguasai tentang pengawasan keuangan daerah dan memecahkan permasalahan yang dihadapi dengan jabatan anggota dewan tersebut. Jadi, dengan adanya pengetahuan maka anggota dewa akan lebih menguasai tetang pegawasan keuangan daerah dan memecahkan masalah yang dihadapi dengan jabatan aggota dewan tersebut.
Adapun indiktor pengetahuan anggota dewan tentang pengawasan anggaran menurut Sopanah dan Isawahyudi (2010) adalah sebagai berikut :

\section{a. Menyusun anggaran (RAPBD/APBD) \\ b. Deteksi serta identifikasi terhadap pemborosan atau kegagalan \\ c. Kebocoran anggaran}

Berdasarkan hasil penelitian, untuk Pengetahuan anggota dewan tentang anggaran (X) hipotesis $\mathrm{H}_{1}$ diterima. Jadi, Pengetahuan anggota dewan tentang anggaran (X) berpengaruh terhadap pengawasan keuangan daerah (APBD).

Pengetahuan anggota dewan tentang anggaran (X) mengalami kenaikan satu satuan, maka Pengawasan Keuangan Daerah (Y) akan mengalami peningkatan. Koefisien bernilai positif artinya antara Pengetahuan anggota dewan tentang anggaran (X) dan Pengawasan Keuangan Daerah (Y) mempunyai pengaruh positif. Kenaikan Pengetahuan anggota dewan tentang anggaran (X) akan mengakibatkan kenaikan pada Pengawasan Keuangan Daerah (Y) yang dilakukan oleh anggota dewan.

Dengan demikian, hasil penelitian ini menemukan bahwa pengetahuan anggota dewan tentang anggaran berpengaruh terhadap pengawasan keuangan daerah.

\section{Transparansi Kebijakan Publik}

Transparansi kebijakan publik atau keterbukaan berarti keputusan yang diambil dan pelaksanaannya dilakukan dengan cara atau mekanisme yang mengikuti aturan atau regulasi yang ditetapkan oleh lembaga. Transparansi kebijakan publik juga bisa berarti bahwa informasi yang berkaitan dengan organisasi tersedia secara mudah dan bebas serta bisa diakses oleh mereka yang terkena dampak kebijakan yang dilakukan oleh organisasi tersebut. Transparansi kebijakan publik juga berarti informasi yang cukup berkaitan dengan kinerja lembaga yang tersedia untuk disajikan dalm bentuk atau media yang mudah dipahami masyarakat, ( Patiar 2013).

Adanya keterbukaan informasi publik secara nyata akan dapat mengurangi daya asimentri informasi. Selain itu, tanpa keterbukaan pemerintahan tidak mungkin masyarakat dapat melakukan partisipasi dalam kegiatan-kegiatan pemerintahan (Kariangan, 2011).

Melalui Informasi yang ada, masyarakat dapat melakukan pengaduan kepada wakilnya yang ada, masyarakat dapat melakukan pengaduan kepada wakilnya yang menduduki jabatan sebagai dewan apabila tahap pelaksanaan dan pertanggungjawaban APBD tidak sesuai dengan harapan masyarakat. 
Adapun indikator tentang transparanski Kebiajakan publik adalah:

1. Keterbukaan tentang anggaran

2. Mudah diakses oleh masyarakat

3. Tindakan yang dilakukan oleh pemerintah

4. Keputusan yang mempunyai ketentuan tertentu

\section{Pengaruh Pengetahuan Anggota Dewan Tentang Anggaran Terhadap Pengawasan Pengawasan Keuangan Daerah dengan Transparansi Kebijakan Publik sebagai Pemoderasi.}

Salah satu kebijakan publik yaitu adanya transparansi, kebijakan pun sangat dibutuhkan oleh masyarakat, karena transparansi dibangun atas dasar arus informasi yang bebas, informasi perlu dapat diakses oleh orang-orang yang berkepentingan dan informasi tersebut harus memadai dan agar dapat dimengerti lalu di pantau oleh orang-orang yang membutuhkan informasi dan dengan adanya kebijakan publik pengawasan keuangan daerah pun akan lebih terarah. Dengan adanya pengetahuan anggota dewan yang baik maka dalam pengambilan keputusan anggota dewan akan lebih berhati-hati dalam pengambilan kebijakan untuk mengawasi keuangan daerah.

Untuk Pengetahuan anggota dewan tentang anggaran dengan transparansi kebijakan publik sebagai pemoderasi $\left(\mathrm{Z}_{1} \mathrm{X}\right)$ Berpengaruh negatif. hipotesis $\mathrm{H}_{2}$ diterima. Jadi, Pengetahuan anggota dewan tentang anggaran berpengaruh terhadap pengawasan keuangan daerah dengan Transparansi kebijakan publik sebagai pemoderasi.

Pengetahuan anggota dewan tentang anggaran (X) mengalami kenaikan satu satuan dan dengan adanya peningkatan Transparansi kebijakan $\left(\mathrm{Z}_{1}\right)$, maka Pengawasan Keuangan Daerah (Y) akan mengalami penurunan. Pengetahuan anggota dewan dengan Transparansi kebijakan sebagai pemoderasi $\left(\mathrm{Z}_{1} \mathrm{X}\right)$ dengan Pengawasan Keuangan Daerah (Y) mempunyai pengaruh negatif. Transparansi kebijakan Publik $\left(\mathrm{Z}_{1}\right)$ memperlemah hubungan Pengetahuan anggota dewan tentang anggaran (X) dengan Pengawasan Keuangan Daerah(Y).

Hal ini mengindikasikan bahwa pengaruh pengetahuan anggaran anggota dewan terhadap pengawasan keuangan daerah diperlemah oleh dengan adanya transparansi kebijakan publik terutama dengan adanya pengumuman kebijakan anggaran kepada masyarakat yang dapat meningkatkan transparansi, kemudahan masyarakat mengakses dokumen publik tentang anggaran, laporan pertanggung jawaban tahunan tepat waktu, kebijakan transparansi anggaran dapat mengakomodir dan memperlemah pendapat usulan rakyat dan adanya sistem pemberian informasi kepada publik yang dapat memperlemah transparansi anggaran, artinya dengan adanya pengumuman kebijakan anggaran kepada masyarakat dan mudah mengakses laporan pertanggung jawaban tahunan tepat waktu tidak serta merta menyebabkan pengetahuan anggaran anggota dewan semakin baik khususnya dalam pengawasan keuangan daerah.

\section{Akuntabilitas}

Akuntabilitas merupakan konsep yang komplek yang lebih sulit mewujudkannya dari pada memberantas korupsi. akuntabilitas adalah keharusan lembaga-lembaga sektor publik untuk lebih menekan pada pertanggungjawaban horizontal (masyarakat) bukan hanya pertanggungjawaban vertikal (otoritas yang lebih tinggi).

Menurut Rasul (2003:8) akuntabilitas adalah kemampuan memberi jawaban kepada otoritas yang lebih tinggi atas tindakan seseorang/sekelompok orang terhadap masyarakat luas dalam suatu organisasi. akuntabilitas merupakan pertanggungjawaban dari seseorang atau sekelompok orang yang diberi amanat untuk menjalankan tugas tertentu. Mardiasmo (2002:20) berpendapat bahwa akuntabilias adalah kewajiban pihak pemegang amanah (agent) untuk memberikan pertanggungjawaban, menyajikan, melaporkan dan mengungkapkan segala aktivitas dan kegiatan yang menjadi tanggungjawabnya kepada pihak pemberi amanah (prinsipal) yang memiliki hak dan kewenangan untuk meminta pertanggungjawaban tersebut.

\section{Pengaruh pengetahuan anggota dewan tentang anggaran terhadap Pengawasan Keuangan Daerah dengan Akuntabilitas}

Akuntabilitas dalam pemerintahan daerah diperlukan guna mewujudkan suatu kondisi yang akuntabel dalam pemerintahan daerah. Sehingga dengan terciptanya kondisi yang akuntabel, memudahkan pengawasan atas kinerja pemerintah itu sendiri dan dengan pengawasan yang baik akan menjadi pemicu kinerja pemerintahan yang semakin baik pula.

Akuntabilitas finansial menekankan pada ukuran anggaran dan finansial. Akuntabilitas pengelolaan keuangan daerah merupakan bagian terpenting dalam mengukur kinerja pemerintah daerah, dimana hasil pertanggungjawaban laporan keuangan memiliki pengaruh yang besar dalam menilai baik buruknya kinerja pemerintah. Dengan adanya akuntabilitas maka pelaporan keuangan daerah yang dilakukan oleh anggota dewan akan lebih berkualitas dan dapat 
dijadikan suatu acuan untuk periode realisasi anggaran di tahun selanjutnya.

Penelitian Darma dan Hasibuan

menyimpulkan bahwa pengetahuan anggaran berpengaruh secara signifikan terhadap pengawasan keuangan daerah yang dilakukan oleh dewan. Namun, penelitian Darma dan Hasibuan tidak sejalan dengan penelitian Ayu Julianastuti (2007) yang menyatakan bahwa akuntabilitas publik tidak dapat memperkuat pengaruh pengetahuan dewan tentang anggaran dengan pengawasan keuangan daerah

Dalam penelitian ini, untuk Pengetahuan anggota dewan tentang anggaran dengan akuntabilitas sebagai pemoderasi $\left(\mathrm{Z}_{2} \mathrm{X}\right)$ dapat pula dikatakan bahwa hipotesis $\mathrm{H}_{3}$ diterima. Jadi, Pengetahuan anggota dewan tentang anggaran berpengaruh terhadap pengawasan keuangan daerah dengan Akuntabilitas sebagai pemoderasi.

Jika Pengetahuan anggota dewan tentang anggaran (X) mengalami kenaikan satu satuan dan dengan adanya peningkatan akuntabilitas $\left(Z_{2}\right)$, maka Pengawasan Keuangan Daerah (Y) akan mengalami peningkatan. Pengetahuan anggota dewan dengan akuntabilitas sebagai pemoderasi $\left(\mathrm{Z}_{2} \mathrm{X}\right)$ dengan Pengawasan Keuangan Daerah (Y) mempunyai pengaruh positif. Akuntabilitas $\left(Z_{2}\right)$ memperkuat hubungan Pengetahuan anggota dewan tentang anggaran (X) dengan Pengawasan Keuangan Daerah (Y).

Hasil penelitian ini menemukan bahwa pengetahuan anggota dewan tentang anggaran dengan akuntabilitas sebagai pemoderasi berpengaruh terhadap pengawasan keuangan daerah. Dengan adanya akuntabilitas publik yang baik dalam menjaga kualitas pengawasan terhadap APBD, maka pengawasan terhadap APBD juga akan semakin baik hasilnya. Hal ini peneliti menegaskan pentingnya akuntabilitas dalam pengawasan keuangan daerah karena dengan adanya akuntabilitas kepada masyarakat masyarakat tidak hanya mengetahui anggaran tersebut tetapi juga mengetahui pelaksanaan kegiatan yang dianggarkan sehingga pemerintah daerah berusaha dengan baik dalam melaksanakan seluruh perencanaan yang ada karena akan dinilai dan diawasi oleh seluruh masyarakat.

4. Pengaruh Pengetahuan Anggota Dewan Tentang Anggaran Terhadap Pengawasan Keuangan Daerah dengan Transparansi Kebijakan Publik dan Akuntabilitas

Transparansi merupakan keterbukaan pemerintah dalam membuat kebijakan keuangan daerah sehingga dapat diketahui dan diawasi oleh DPRD dan masyarakat Mardiasmo, (2002:30 Ayu Julianastuti 2007). Akuntabilitas mensyaratkan pengambilan keputusan berprilaku telah sesuai dengan aturan yang berlaku. Pada dasarnya akuntablitas publik adalah pemberian informasi dan disclosure yang berkepentingan dengan laporan tersebut, Mardiasmo, (2001:31 dalam Ayu Julianastuti (2007).

Pengetahuan anggota dewan tentang anggaran berpengaruh terhadap pengawasan keuangan daerah dengan transparansi kebijakan publik yang menunjukkan pengaruh negatif, dan pengetahuan anggota dewan tentang anggaran terhadap pengawasan keuangan daerah dengan akuntabilitas sebagai variabel pemoderasi menunjukkan pengaruh positif.

\section{Kerangka Konseptual}

Adapun kerangka konseptual dalam penelitian ini adalah sebagai berkut:

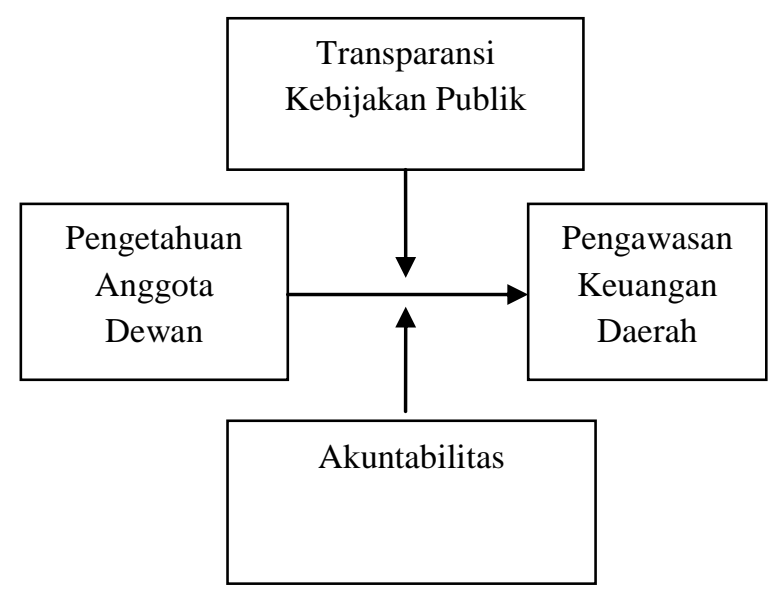

Gambar 1 Kerangka Konseptual

\section{METODE PENELITIAN}

\section{Lokasi dan obyek penelitian}

Lokasi penelitian ini dilakukan di wilayah Aceh tepatnya di Dewan Perwakilan Rakyat Daerah (DPRD) Aceh Utara Jl. Mayjen Nyak Adam Kamil No.1, Simpang Empat, Kota Lhokseumawe, Aceh. Pengambilan data menggunakan survey langsung dan instrument yang digunakan adalah kuesioner. Sampel dari penelitian ini adalah semua anggota dewan yang ada di DPRD Aceh Utara, dari jumlah tersebut, kuesioner diharapkan kembali sebanyak-banyak mungkin.

Dalam penelitian ini, objek penelitian adalah pengetahuan anggota dewan tentang anggaran $\left(X_{1}\right)$, transparansi kebijakan publik $\left(\mathrm{Z}_{1}\right)$, akuntabilitas $\left(\mathrm{Z}_{2}\right)$, dan pengawasan keuangan daerah (Y).

\section{Populasi}


Populasi dan sampel penelitian ini adalah seluruh anggota DPRD Kabupaten Aceh Utara. Populasi dalam penelitian ini semua dijadikan sampel. Pengumpulan data dalam penelitian ini menggunakan survey langsung. Metode yang digunakan adalah metode sensus yaitu metode pengambilan sampel yang berdasarkan keseluruhan populasi atau sering disebut sampling jenuh. Instrumen yang digunakan adalah kuesioner. Penyebaran kuesioner dilakukan dengan cara mengunjungi dan membagi kuesioner kepada responden di DPRK Kabupaten Aceh Utara. Daftar pertanyaan Variabel pengetahuan anggota dewan tentang anggaran, Transparansi Kebijakan Publik dan Akuntabilitas.

Penelitian ini merupakan penelitian kuantitatif terhadap DPRK Kabupaten Aceh Utara Periode 2014-2019, bertujuan untuk mendapatkan gambaran mengenai tingkat pengawasan Keuangan Daerah (APBD), dipengaruhi oleh tingkat pengetahuan dewan tentang anggaran, dan seberapa besar pengaruh transparansi kebijakan publik dan akuntabilitas terhadap hubunganya dengan pengawasan keuangan daerah.

\section{Teknik pengumpulan data}

Penelitian ini menggunakan data primer yaitu sumber data penelitian yang diperoleh secara langsung dari sumber aslinya yang berupa pertanyaanpertanyaan yang mengacu pada kuesioner dari individu atau kelompok (orang) maupun hasil observasi dari suatu obyek, kejadian atau hasil pengujian (benda). Dengan kata lain, peneliti membutuhkan pengumpulan data dengan cara menjawab pertanyaan riset (metode survei) atau penelitian benda (metode observasi).
a. Kuesioner (Angket)
b. Dokumentasi

\section{HASIL PENELITIAN DAN PEMBAHASAN}

\section{Gambaran Umum}

Kabupaten Aceh Utara adalah sebuah kabupaten di Propinsi Aceh. Secara geografis Kabupaten ini terletak di bagian pantai pesisir utara pada 96.52.000 (derjat)-97.31.000 (derjat) bujur timur dan $\quad 04.46 .000$ (derjat)-05.00.400 (derjat) lintang utara. Kabupaten yang di gelar dengan bumi Malikussaleh ini, memiliki wilayah seluas 3.477.92 $\mathrm{Km}^{2}$ yang memiliki batas - batas sebagai berikut :

1. Sebelah utara dengan Kota Lhokseumawe dan selat malaka

2. Sebelah selatan dengan Kabupaten Bener Meriah

3. Sebelah timur dengan Kabupaaten Aceh Timur

4. Sebelah barat dengan Kabupaten Bireuen DPRK Aceh Utara masa jabatan tahun 2014 - 2019 telah di lantik pada tanggal 01 september 2014 yang berjumlah 45 orang dengan komposisi :

5. Dari Partai Aceh : 24 Kursi

6. Dari Partai Persatuan Pembangunan: 6 Kursi

7. Dari Partai Nasional Demokrat: 5 Kursi

8. Dari Partai Amanat Nasional: 3 Kursi

9. Dari Partai Nasional Aceh : 2 Kursi

10. Dari Partai Golongan Karya : 2 Kursi

11. Dari Partai Kebangkitan Bangsa: 1 Kursi

12. Dari Partai Demokrat : 1 Kursi

13. Dari Partai Gerakan Indonesia Raya : 1 Kursi

14. Jumlah Keseluruhan : 45 Kursi

\section{Uji Heteroskedastisitas}

Deteksi ada atau tidaknya heteroskedastisitas dapat dilakukan dengan melihat ada atau tidaknya pola tertentu pada grafik scatterplot. Dalam penelitian menemukan bahwa tidak terjadinya heteroskedastisitas di tunjukan pada gambar hasil uji heteroskedastisitas dimana dalam penelitian ini menunjukkan titik-titik menyebar tanpa pola yang jelas serta tersebar di atas maupun di bawah angka 0 pada sumbu Y.

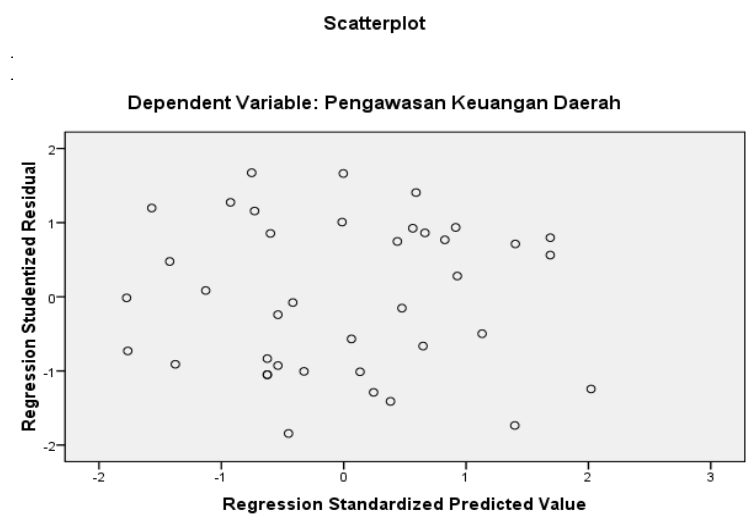

Gambar 2 hasil Uji Heteroskedastisitas

dalam persamaan regresinya terkandung unsur interaksi (terdapat variabel moderasi).

Tabe 1. Moderated Regression Analysis

\begin{tabular}{|l|c|c|c|c|c|}
\hline & \multicolumn{2}{|c|}{$\begin{array}{c}\text { Unstandardi } \\
\text { zed } \\
\text { Coefficients }\end{array}$} & $\begin{array}{c}\text { Standardiz } \\
\text { ed } \\
\text { Coefficient } \\
\text { s }\end{array}$ & & \\
\cline { 2 - 4 } & Model & $\begin{array}{c}\text { Std. } \\
\text { Error }\end{array}$ & Beta & $\mathrm{t}$ & Sig. \\
\hline 1 (Constant) & 2.306 & .474 & & 4.863 & .000 \\
\hline
\end{tabular}




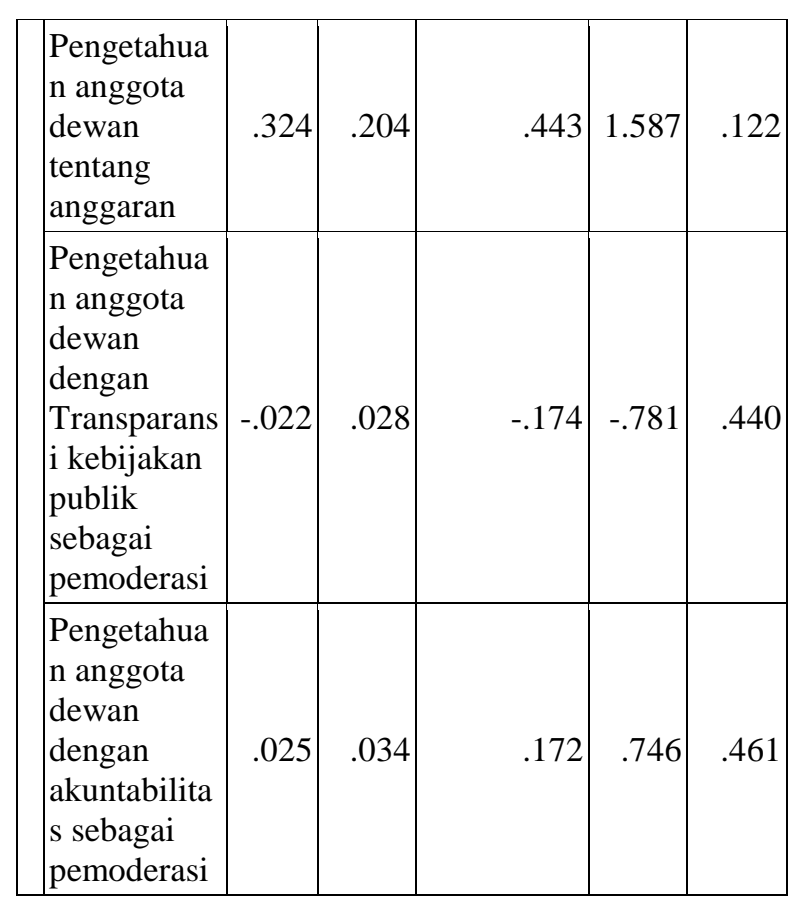

$Y=2,306+0,324 X-0,022 \quad Z_{1} X+0,025 \quad Z_{2} X+e$

Berdasarkan data diatas dapat dinyatakan bahwa pengetahuan anggota dewan tentang anggaran (X) berpengaruh positif artinya pengetahuan anggota dewan tentang anggaran (X) dapat memperkuat pengawasan keuangan daerah, pengetahuan anggota dewan tentang anggaran (X) dengan Transparansi kebijakan publik (Z1) sebagai pemoderasi berpengaruh negatif terhadap pengawasan keuangan daerah (Y), artinya Transparansi kebijakan Publik (Z1) dapat memperlemah hubungan pengetahuan anggota dewan tentang anggaran (X), pengetahuan anggota dewan tentang anggaran (X) dengan akuntabilitas (Z2) sebagai pemoderasi berpengaruh positif, dengan adanya akuntabilitas (Z2) maka dapat memperkuat hubungan pengetahuan anggota dewan tentang anggaran $(\mathrm{X})$ dengan pengawasan keuangan daerah (Y).
Keuangan Daerah. Hal ini di karenakan nilai Koefisien Korelasi berada di antara 0,40-0,599 yang artinya mempunyai keeratan atau kekuatan hubungan yang sedang antara variabel independen yaitu Pengetahuan anggota dewan tentang anggaran (X), Pengetahuan anggota dewan dengan Transparansi kebijakan Publik sebagai pemoderasi $\left(\mathrm{Z}_{1} \mathrm{X}\right)$, dan Pengetahuan anggota dewan dengan akuntabilitas sebagai pemoderasi $\left(\mathrm{Z}_{2} \mathrm{X}\right)$ dengan variabel dependen (Y) Pengawasan Keuangan Daerah.

\section{Hasil Uji Koefision Determinasi}

Tabel 3. Hasil Uji Determinasi Model Summary ${ }^{b}$

\begin{tabular}{|l|c|c|r|r|}
\hline Model & $\mathrm{R}$ & $\begin{array}{c}\mathrm{R} \\
\text { Squar } \\
\mathrm{e}\end{array}$ & $\begin{array}{c}\text { Adjusted R } \\
\text { Square }\end{array}$ & $\begin{array}{c}\text { Std. Error of } \\
\text { the Estimate }\end{array}$ \\
\hline 1 & $.473^{\mathrm{a}}$ & .224 & .157 & .28184 \\
\hline
\end{tabular}

Berdasarkan tabel di atas menyatakan bahwa nilai koefisien determinasi ( $R$ Square) adalah 0,224. Dalam penelitian ini menggunakan nilai R Square Hal ini berarti bahwa Pengawasan Keuangan Daerah bisa dipengaruhi oleh Pengetahuan anggota dewan tentang anggaran (X), Pengetahuan anggota dewan dengan Transparansi kebijakan Publik sebagai pemoderasi $\left(\mathrm{Z}_{1} \mathrm{X}\right)$, dan Pengetahuan anggota dewan dengan akuntabilitas sebagai pemoderasi $\left(Z_{2} X\right)$ sebesar 0,224. Sedangkan sisanya dijelaskan oleh variabel lain yang tidak ada dalam penelitian ini. Nilai $\mathrm{R}^{2}$ tersebut dapat dikatakan agak kecil (mendekati 0), yang berarti kemampuan variabel-variabel Pengetahuan Anggota Dewan Tentang Anggaran dalam menjelaskan variasi variabel Pengawasan Keuangan Daerah terbatas.

\section{Hasil Pengujian Hipotesis}

Tabel 4. Hasil Pengujian Hipotesis

\section{Hasil Uji koefisien korelasi (R)}

Tabel 2. Hasil Uji Koefisien Korelasi (R)

\begin{tabular}{|l|c|r|r|r|}
\hline Model & $\mathrm{R}$ & R Square & $\begin{array}{l}\text { Adjusted } \\
\text { R Square }\end{array}$ & $\begin{array}{r}\text { Std. Error of } \\
\text { the Estimate }\end{array}$ \\
\hline 1 & $.473^{\mathrm{a}}$ & .224 & .157 & .28184 \\
\hline
\end{tabular}

\begin{tabular}{|c|c|c|c|c|c|}
\hline \multirow{2}{*}{ Model } & \multicolumn{2}{|c|}{$\begin{array}{c}\text { Unstandardiz } \\
\text { ed } \\
\text { Coefficients }\end{array}$} & $\begin{array}{c}\text { Standardiz } \\
\text { ed } \\
\text { Coefficient } \\
\text { s }\end{array}$ & \multirow{2}{*}{ T } & Sig. \\
\cline { 2 - 6 } & $\mathrm{B}$ & $\begin{array}{c}\text { Std. } \\
\text { Error }\end{array}$ & Beta & & \\
\hline 1 (Constant) & 2.306 & .474 & & 4.863 & .000 \\
\hline
\end{tabular}

Berdasarkan tabel diatas diperoleh nilai koefisien korelasi $(\mathrm{R})$ sebesar 0,473. Ini menunjukkan bahwa semua variabel independen mempunyai tingkat hubungan yang sedang terhadap Pengawasan 


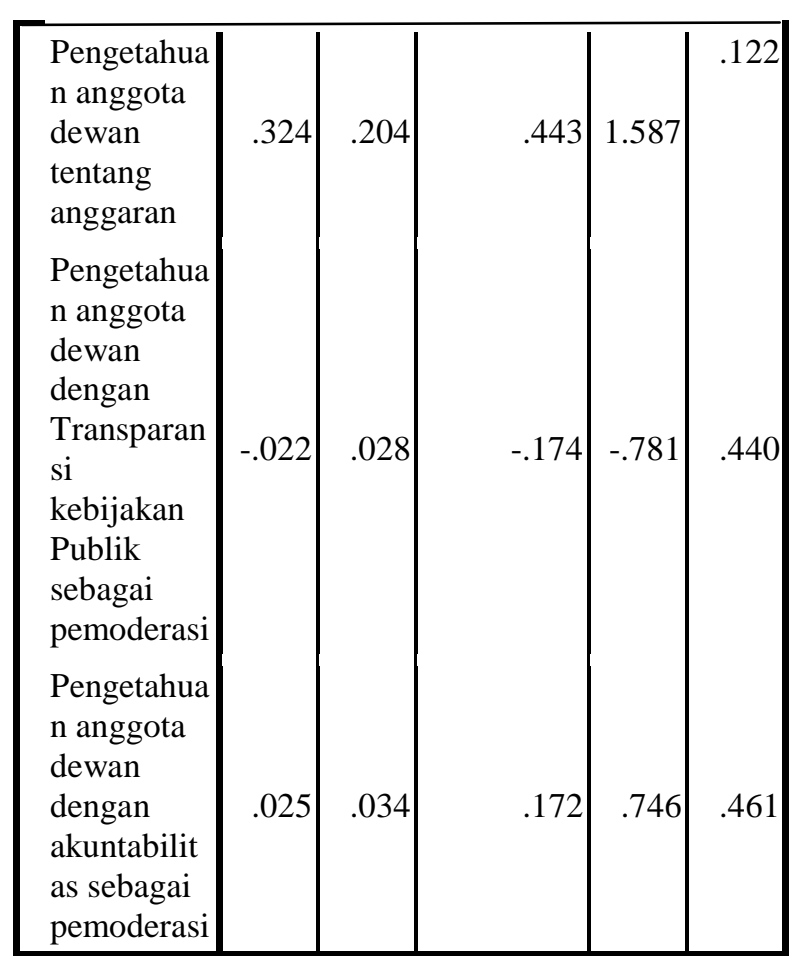

Berdasarkan pada tabel 4.26 diatas dapat dilihat bahwa nilai $b_{1}$ untuk Pengetahuan anggota dewan tentang anggaran (X) yaitu 0,324. Maka, hipotesis $\mathrm{H}_{1}$ diterima. Jadi, dengan demikian dapat dikatakan bahwa Pengetahuan anggota dewan tentang anggaran (X) berpengaruh terhadap pengawasan keuangan daerah $(\mathrm{Y})$.

Dari tabel diatas dapat dilihat nilai $b_{2}$ untuk Pengetahuan anggota dewan tentang anggaran dengan transparansi kebijakan publik sebagai pemoderasi $\left(\mathrm{Z}_{1} \mathrm{X}\right)$ yaitu $-0,022$. Maka, hipotesis $\mathrm{H}_{2}$ diterima. Jadi, dapat dikatakan bahwa Pengetahuan anggota dewan tentang anggaran berpengaruh terhadap pengawasan keuangan daerah dengan Transparansi kebijakan publik sebagai pemoderasi.

Dari tabel diatas dapat nilai nilai $b_{3}$ utk Pengetahuan anggota dewan tentang anggaran dengan akuntabilitas sebagai pemoderasi $\left(\mathrm{Z}_{2} \mathrm{X}\right)$ yaitu 0,025 . Maka, dapat pula dikatakan bahwa hipotesis $\mathrm{H}_{3}$ diterima. Jadi, Pengetahuan anggota dewan tentang anggaran berpengaruh terhadap pengawasan keuangan daerah dengan Akuntabilitas sebagai pemoderasi.

\section{Pembahasan Hasil Penelitian}

\section{Pengaruh Pengetahuan Anggota Dewan tentang Anggaran terhadap Pengawasan Keuangan Daerah}

Berdasarkan hasil penelitian, Nilai $b_{1}$ untuk Pengetahuan anggota dewan tentang anggaran (X) yaitu 0,324, Artinya hipotesis $\mathrm{H}_{1}$ diterima. Jadi, Pengetahuan anggota dewan tentang anggaran (X) berpengaruh terhadap pengawasan keuangan daerah (APBD). Konstanta $(\alpha)$ sebesar 2,306. Bila variabel independen bernilai 0, maka variabel Pengawasan Keuangan Daerah (Y) akan bernilai 2,306. Dan Koefisien $\left(b_{1}\right)$ sebesar 0,324 merupakan nilai koefisien regresi variabel Pengetahuan anggota dewan tentang anggaran (X) terhadap variabel Pengawasan Keuangan Daerah (Y). Artinya jika Pengetahuan anggota dewan tentang anggaran (X) mengalami kenaikan satu satuan, maka Pengawasan Keuangan Daerah (Y) akan mengalami peningkatan sebesar 0,324. Koefisien bernilai positif artinya antara Pengetahuan anggota dewan tentang anggaran (X) dan Pengawasan Keuangan Daerah (Y) mempunyai pengaruh positif. Kenaikan Pengetahuan anggota dewan tentang anggaran (X) akan mengakibatkan kenaikan pada Pengawasan Keuangan Daerah (Y) yang dilakukan oleh anggota dewan.

\section{Pengaruh Pengetahuan Anggota Dewan tentang Anggaran terhadap Pengawasan Keuangan Daerah dengan Transparansi Kebijakan Publik sebagai pemoderasi}

Nilai $b_{2}$ untuk Pengetahuan anggota dewan tentang anggaran dengan transparansi kebijakan publik sebagai pemoderasi $\left(Z_{1} X\right)$ yaitu -0,022 Maka, hipotesis $\mathrm{H}_{2}$ diterima. Jadi, Pengetahuan anggota dewan tentang anggaran berpengaruh terhadap pengawasan keuangan daerah dengan Transparansi kebijakan publik sebagai pemoderasi. Dari hasil uji hipotesis dengan menggunakan uji Regresi B sehingga pengetahuan anggota dewan tentang anggaran dengan transparansi kebijakan publik menunjukkan berpengaruh negatif terhadap pengawasan keuangan daerah.

Koefisien $\left(b_{2}\right)$ sebesar -0,022 merupakan nilai koefisien regresi Pengetahuan anggota dewan dengan Transparansi kebijakan Publik sebagai pemoderasi $\left(Z_{1} X\right)$ terhadap variabel Pengawasan Keuangan Daerah (Y). Artinya jika Pengetahuan anggota dewan tentang anggaran (X) mengalami kenaikan satu satuan dan dengan adanya peningkatan Transparansi kebijakan $\left(\mathrm{Z}_{1}\right)$, maka Pengawasan Keuangan Daerah (Y) akan mengalami penurunan sebesar 0,022. Koefisien bernilai negatif artinya Pengetahuan anggota dewan dengan Transparansi kebijakan sebagai pemoderasi $\left(\mathrm{Z}_{1} \mathrm{X}\right)$ dengan Pengawasan Keuangan Daerah (Y) mempunyai pengaruh negatif. Transparansi kebijakan Publik $\left(\mathrm{Z}_{1}\right)$ memperlemah hubungan Pengetahuan anggota dewan tentang anggaran (X) dengan Pengawasan Keuangan Daerah(Y). 


\section{Pengaruh Pengetahuan Anggota Dewan tentang Anggaran terhadap Pengawasan Keuangan Daerah dengan Akuntabilitas sebagai pemoderasi}

Nilai $b_{3}$ untuk Pengetahuan anggota dewan tentang anggaran dengan akuntabilitas sebagai pemoderasi $\left(\mathrm{Z}_{2} \mathrm{X}\right)$ yaitu 0,025 Maka, dapat pula dikatakan bahwa hipotesis $\mathrm{H}_{3}$ diterima. Jadi, Pengetahuan anggota dewan tentang anggaran berpengaruh terhadap pengawasan keuangan daerah dengan Akuntabilitas sebagai pemoderasi.

Koefisien $\left(b_{3}\right)$ sebesar 0,025 merupakan nilai koefisien regresi Pengetahuan anggota dewan dengan akuntabilitas sebagai pemoderasi $\left(\mathrm{Z}_{2} \mathrm{X}\right)$ terhadap variabel Pengawasan Keuangan Daerah (Y). Artinya jika Pengetahuan anggota dewan tentang anggaran (X) mengalami kenaikan satu satuan dan dengan adanya peningkatan akuntabilitas $\left(\mathrm{Z}_{2}\right)$, maka Pengawasan Keuangan Daerah (Y) akan mengalami peningkatan sebesar 0,025 . Koefisien bernilai positif artinya Pengetahuan anggota dewan dengan akuntabilitas sebagai pemoderasi $\left(\mathrm{Z}_{2} \mathrm{X}\right)$ dengan Pengawasan Keuangan Daerah (Y) mempunyai pengaruh positif. Akuntabilitas $\left(\mathrm{Z}_{2}\right)$ memperkuat hubungan Pengetahuan anggota dewan tentang anggaran (X) dengan Pengawasan Keuangan Daerah (Y).

Hasil penelitian ini menemukan bahwa pengetahuan anggota dewan tentang anggaran dengan akuntabilitas sebagai pemoderasi berpengaruh terhadap pengawasan keuangan daerah. Penelitian ini sejalan dengan penelitian Arianti (2017) dan Setiawati (2010) yang mengemukakan bahwa pengetahuan anggota dewan tentang anggaran dengan akuntabilitas sebagai variabel pemoderasi berpengaruh terhadap pengawasan keuangan daerah.

Dengan adanya akuntabilitas publik yang baik dalam menjaga kualitas pengawasan terhadap APBD, maka pengawasan terhadap APBD juga akan semakin baik hasilnya. Hal ini peneliti menegaskan pentingnya akuntabilitas dalam pengawasan keuangan daerah karena dengan adanya akuntabilitas kepada masyarakat masyarakat tidak hanya mengetahui anggaran tersebut tetapi juga mengetahui pelaksanaan kegiatan yang dianggarkan sehingga pemerintah daerah berusaha dengan baik dalam melaksanakan seluruh perencanaan yang ada karena akan dinilai dan diawasi oleh seluruh masyarakat.

\section{PENUTUP}

\section{KESIMPULAN}

Berdasarkan uraian-uraian sebagaimana yang telah dijelaskan di bab terdahulu, maka dapat disimpulkan sebagai berikut:
1. Pengetahuan anggota dewan tentang anggaran (X) terhadap Pengawasan keuangan daerah $(\mathrm{Y})$. dengan demikian, hasil penelitian ini menemukan bahwa pengetahuan anggota dewan tentang anggaran (X) berpengaruh positif terhadap pengawasan keuangan daerah $(\mathrm{Y})$.

2. Pengetahuan anggota dewan tentang anggaran (X) terhadap pengawasan keuangan daerah $(\mathrm{Y})$ dengan transparansi kebijakan publik sebagai pemoderasi $\left(\mathrm{Z}_{1} \mathrm{X}\right)$ hipotesis $\mathrm{H}_{2}$ diterima. Jadi, pengetahuan anggota dewan tentang anggaran berpengaruh terhadap pengawasan keuangan daerah dengan transparansi kebijakan publik sebagai pemoderasi. hasil penelitian pengetahuan anggaran anggota dewan dengan transparansi kebijakan publik yang menyatakan bahwa pengetahuan anggota dewan tentang anggaran dengan transparansi kebijakan publik menunjukkan pengaruh negatif terhadap pengawasan keuangan daerah.

3. Pengetahuan anggota dewan tentang anggaran (X) berpengaruh terhadap pengawasan keuangan daerah (Y) dengan akuntabilitas (Z2) sebagai pemoderasi. maka, dapat pula dikatakan bahwa hipotesis $\mathrm{H}_{3}$ diterima. Jadi, Pengetahuan anggota dewan tentang anggaran berpengaruh terhadap pengawasan keuangan daerah dengan akuntabilitas sebagai pemoderasi. Jadi, Hasil penelitian ini menemukan bahwa pengetahuan anggota dewan tentang anggaran (X) terhadap pengawasan keuangan daerah (Y) dengan akuntabilitas (Z2) sebagai pemoderasi berpengaruh terhadap pengawasan keuangan daerah $(\mathrm{Y})$.

4. Pengetahuan anggota dewan tentang anggaran berpengaruh terhadap pengawasan keuangan daerah dengan transparansi kebijakan publik yang menunjukkan pengaruh negatif, dan pengetahuan anggota dewan tentang anggaran terhadap pengawasan keuangan daerah dengan akuntabilitas sebagai variabel pemoderasi menunjukkan pengaruh positif.

\section{Keterbatasan Penelitian}

1. Populasi yang digunakan dalam penelitian ini yaitu seluruh anggota Dewan Perwakilan Rakyat Kabupaten Aceh Utara (DPRK) pada periode 2014-2019 yang didominasi oleh parpol tertentu sehingga tidak dapat digeneralisasikan secara lebih luas.

2. Dalam penelitian ini hanya menggunakan dua variabel pemoderasi yaitu transparansi kebijakan publik dan akuntabilitas sehingga terabaikannya variabel lain yang mungkin dapat memperkuat atau memperlemah 
hubungan pengetahuan anggota dewan dengan pengawasan keuangan daerah.

\section{Saran}

1. Sebagai bahan pertimbangan dan masukan kepada pemerintah daerah dalam meningkatkan pemahaman dan kinerja pemerintah daerah.

2. Hasil penelitian ini diharapkan dapat memberi sumbangan pemikiran dalam mengembangkan konsep mengenai pengaruh pengetahuan anggota dewan tentang anggaran terhadap pengawasan keuangan daerah sebagai variabel moderating. Selanjutnya diharapkan kepada penelitia selanjutnya untuk menambah atau menggunakan variabel-variabel lain yang konstan dengan penlitian ini dan dapat dilakukannya moderasi.

Contohnya :

a. Pengaruh pengetahuan anggota dewan tentang anggaran terhadap pengawasan keuangan daerah dengan komitmen organisasi dan transparansi kebijakan publik sebagai variabel moderating.

b. Pengaruh pengetahuan dewan tentang anggaran terhadap pengawasan pada anggaran pendapatan belanja daerah (APBD): komitmen organisasi sebagai variabel moderating.

c. Pengaruh pengetahuan anggota dewan tentang anggaran terhadap pengawasan keuangan daerah dengan political background, akuntabilitas publik dan transparansi kebijakan publik sebagai variabel moderating.

\section{DAFTAR PUSTAKA}

Abdul Halim. (2007). Akuntansi Sektor Publik Akuntansi keuangan daerah, Edisi Revisi, Jakarta, Salemba Empat.

Abdul Halim dan Muhammad Iqbal. (2012). Bunga Rampai Manajemen Keuangan Daerah, Edisi Ketiga. Jogjakarta : Penerbit UPP AMP YKPN.

Abidin, Said Zainal. 2004. Kebijakan Publik. Jakarta: Yayasan Pancur Siwah

Abdurrahmat Fathoni. 2006. Manajemen Sumber daya Manusia. Rineka Cipta, Jakarta.

Aceh Utara. 2014. Nama-Nama DPRK Pemerintah Kabupaten Aceh Utara Tahun 20142019.http://www.ajnn.net/news/nama-namadprk-aceh-utara/index.html. (dikunjungi pada 18/11/2017).
Aditya Dibyo Saputro. 2012. Pengaruh Partisipasi Masyarakat Dan Transparansi Kebijakan Publik Terhadap Hubungan Antara Pengetahuan Dewan Tentang Anggaran Dengan Pengawasan Keuangan Daerah (Studi Empiris Di Dprd Kab. Boyolali). Naskah Publikasi. Universitas Muhammadiyah Surakarta.

Agsarini, I. \& Wiguna, I.P., 2015. Pengaruh Faktor Kondisi Proyek terhadap Kinerja Proyek Konstruksi. In Seminar Nasional Manajemen Teknologi XXII. Surabaya, 2015. Program Studi MMT-ITS.

Aras Aira. 2011. Pengaruh Pengetahuan Anggota DPRD Tentang Anggaran Terhadap Efektifitas Pengawasan Anggaran (Studi Empiris Pada Kabupaten Kampar). Universitas Islam Negeri sultan syarif kasim. Riau

Arini Ayu Rahmawati. 2013. Pengaruh Partisipasi Masyarakat Dan Transparansi Kebijakan Publik Terhadap Pengawasan Keuangan Daerah Di Kabupaten Sukoharjo. Universitas Muhammadiyah Surakarta

Ayu Julianastuti. 2013. Pengaruh Akuntabilitas Publik, Partisipasi Masyarakat Dan Transparansi Kebijakan Publik Terhadap Hubungan Pengetahuan Dewan Tentang Anggaran Dengan Pengawasan Keuangan Daerah (Studi Empiris Pada Dprd Kota Di Provinsi Sumatera Barat). Universitas Negeri Padang (Unp).

Darma, J dan Hasibuan, A, F. 2012, Pengaruh Pengetahuan Anggota Dewan Tentang Anggaran Terhadap Pengawasan Keuangan Daerah dengan Partisipasi Masyarakat Sebagai Variabel Pemoderasi, Jurnal Mediasi, Vol. 4, No. 1 Juni, Medan.

Dedi Rudiyanto. 2012. Pengaruh Pengetahuan Anggota Dewan Tentang Anggaran Terhadap Pengawasan Keuangan Daerah (APBD) Dengan Partisipasi Masyarakat Dan Transparansi Kebijakan Publik Dengan Variabel Moderating Studi Empiris pada DPRD Kabupaten Karanganyar. Fakultas Ekonomi Universitas Muhammadiyah Surakarta.

Dunn,William $\mathrm{N}$. 2003. PengantarAnalisisKebijakanPublik. Gadjah Mada University Press, Yogyakarta 
Dedi Nordiawan dkk, 2007. Akuntansi Pemerintahan , Jakarta : Salemba Empat

Dewa Gede Sudiarta, Ni Luh Gede Erni Sulindawati dkk. 2014. Analisis Pengaruh Pengetahuan Dewan Tentang Anggaran terhadap Pengawasan Keuangan Daerah Dengan Akuntabilitas Publik, Partisipasi Masyarkat, dan Transparansi Kebijakan Publik Sebagai Variabel Moderating (Studi empiris pada lembaga DPRD kabupaten Buleleng). Universitas Pendidikan Ganesha, Singaraja Indonesia. (Volume: 2 No. 1 Tahun 2014).

Elsi Erianti. 2017. Pengaruh Pengetahuan Anggota Dewan Tentang Anggaran terhadap Pengawasan Keuangan Daerah dengan Political Background, Akuntabilitas dan Transparansi Kebijakan Publik sebagai Variabel Pemoderasi. Fakultas Ekonomi. Universitas Riau. JOM Fekon, Vol 4 (1 Februari 2017).

Fifit Purnama Dan Nadirsyah. 2016. Pengaruh Pengawasan Keuangan Daerah, Akuntabilitas, Dan Transparansi Pengelolaan Keuangan Daerah Terhadap Kinerja Pemerintah Daerah Pada Kabupaten Aceh Barat Daya. Fakultas Ekonomi dan Bisnis Universitas Syiah Kuala. Jurnal Ilmiah Mahasiswa Ekonomi Akuntansi (JIMEKA) Vol. 1, No. 2, (2016) Halaman 01-15

Ghozali, imam. 2005. Aplikasi Analisis Mulltivariate dengan SPSS. Semarang: Badan Penerbitan UNDIP.

Hasibuan, Malayu.S.P. 1997, Manajemen Sumber Daya Manusia dan Kunci Keberhasilan,Jakarta: Haji Masagung.

Hartono, Rengkin Ramang. (2016). Pengetahuan Anggota Dewan Tentang Anggaran terhadap Pengawasan APBD Dengan Komitmen Organisasi Sebagai Variabel Moderating (Studi Empiris pada DPRD Kabupaten Jember). Skripsi Progam Sarjana (S1) Pada Program Sarjana Fakultas Ekonomi Universitas Jember.

Jufri Darma, Ali Fikri Hasibuan. 2012. Pengaruh Pengetahuan Anggota Dewan Tentang Anggaran Terhadap Pengawasan Keuangan Daerah Dengan Partisipasi Masyarakat Sebagai Variabel Moderating. Universitas Negeri Medan. Vol. 4 N0.1 Juni 2012
Kariangan, 2011. Partisipasi Masyarakat dalam Pengelolaan Keuangan Daerah. Bandung: Alumni

Krina dan Peters ,2003. Indikator Dan Alat Ukur Prinsip Akuntabilitas, Transparansi dan Partisipasi, Sekretariat Good Governance Badan Perencanaan Pembangunan Nasional, Jakarta.

Kurnia Utami, Efrizal Syofyan. 2013. Pengaruh Pengetahuan Dewan Tentang Anggaran Terhadap Pengawasan Keuangan Daerah Dengan Variabel Pemoderasi Partisipasi Masyarakat Dan Transparansi Kebijakan Publik. FE UNP. Jurnal WRA, Vol. 1, No. 1 April 2013.

Made Budi Sastra Wiguna. 2015. Pengaruh Pengawasan Keuangan Daerah, Akuntabilitas Dan Transparansi Pengelolaan Keuangan Daerah Terhadap Kinerja Pemerintah Daerah Kabupaten Buleleng. Jurusan Akuntansi Program S1 Universitas Pendidikan Ganesha Singaraja, Indonesia. Volume 3 No.1 Tahun 2015

Mahmudi, 2010, Manajemen Kinerja Sektor Publik, UPP STIM YKPN, Yogyakarta

Mansyur Faqih. 2014. Fitra Sebut Aceh Utara Peringkat Satu Penyimpangan Anggaran di Aceh Republika.Co.Id, Banda Aceh. Sumber : Antara. Dikunjungi Pada 29/11/2017

Mardiasmo. 2002. Akuntansi Sektor Publik. Penerbit Andi. Yogyakarta

Maulana Hardia Utama. 2015. Pengaruh Pengetahuan Dewan Tentang Anggaran Terhadap Pengawasan Keuangan Daerah Dengan Partisipasi Masyarakat Dan Transparansi Kebijakan Publik Sebagai Variabel Moderating. ( Studi Empiris pada DPRD Kabupaten Boyolali ). Fakultas Ekonomi Dan Bisnis Universitas Muhammadiyah Surakarta.

Mulyana, Budi, 2006. Pengaruh Penyajian Neraca Daerah dan Aksesibilitas Laporan Keuangan Daerah Terhadap Transparansi dan Akuntabilitas Pengelolaan Keuangan Daerah, Jurnal Akuntansi Pemerintahan, volume 2, Nomor 1, Universitas Gajah Mada, hal 56.

Ni Made Ana Rosita. Nyoman Trisna Herawati dkk. 2015. Pengaruh Latar Belakang Anggota Dewan Dan Pengetahuan Dewan Tentang 
Anggaran Terhadap Pengawasan

Keuangan Daerah (Apbd) Dengan Variabel Moderating Transparansi Kebijakan Publik (Studi Kasus Pada Kantor DPRD Kabupaten Tabanan). Universitas Pendidikan Ganesha Singaraja, Indonesia. Volume 2 No. 1 Tahun 2014

Patiar, Sri Rustiyaningsih, dkk. 2014. Pengaruh Pengetahuan Dewan Tentang Anggaran Terhadap Pengawasan Keuangan Daerah (Apbd) Dengan Variabel Moderating Partisipasi Masyarakat Dan Transparansi Kebijakan Publik (Studi Empiris Pada Anggota Dprd Di Kab. Landak Dan Kabupaten Sanggau Propinsi Kalimantan Barat 2013). Jurnal Riset Manajemen dan Akuntansi. Vol. 02 No. 01, ISSN Online: 2338-6576, Hal: $14-24$

Peraturan Menteri Dalam Negeri Nomor 59 Tahun 2007 tentang Perubahan Atas Peraturan Menteri Dalam Negeri Nomor 13 Tahun 2006 tentang Pedoman Pengelolaan Keuangan Daerah.

Putu Ratih Pratiwi, I Made Pradana Adiputra, dkk. 2015. Pengaruh Pengawasan Keuangan Daerah, Sumber Daya Manusia, Pemanfaatan Teknologi Informasi, Dan Pengendalian Intern Akuntansi Terhadap Nilai Informasi Pelaporan Keuangan Pemerintah Daerah (Studi Kasus Pada Satuan Kerja Perangkat Daerah Kabupaten Tabanan). Universitas Pendidikan Ganesha Singaraja Indonesia. Volume 3 No. 1 Tahun 2015

R. Ait Novianti dan Nurmalita lestari (2003). Pengaruh Akuntabilitas publik, partisipasi masyarakat dan transparansi kebijakan publik terhadap pengawasan keuangan daerah (APBD) di DPRD kota Bandung.

Rasul, Syahrudin, 2003. Pengintegrasian Sistem Akuntabilitas Kinerja dan Anggaran dalam Perspektif UU NO. 17/2003 Tentang Keuangan Negara. Jakarta: PNRI

Republik Indonesia. 2004. Undang-undang Nomor 32 Tahun 2004 tentang Pemerintah Daerah. Jakarta.

Republik Indonesia. 2005. Peraturan Pemerintah Nomor 58 Tahun 2005 Tentang Pengelolaan Keuangan daerah. Jakarta.

Simson Werimon, 2007. Pengaruh Partisipasi Masyarakat Dan Transparansi Kebijakan
Publik Terhadap Hubungan Antara Pengetahuan Dewan Tentang Anggaran Dengan Pengawasan Keuangan Daerah (APBD) (Study Empiris Di Provinsi Papua). Universitas Papua.

Sugiyono, 2007, Metode Penelitian Kuantitatif Kualitatif dan $\boldsymbol{R} \& \boldsymbol{D}$. Bandung: Alfabeta

Sugiyono. 2010. Metode Penelitian Pendidikan Kuantitatif, Kualitatif dan $R \& D$. Bandung: Alfabert.

Suryanto. 2015. Pengaruh Pengetahuan Anggota Dewan Tentang Anggaran Terhadap Pengawasan Keuangan Daerah Dengan Partisipasi Masyarakat Dan Akuntabilitas Sebagai Variabel Moderating ( Studi Empiris Di Kabupaten Boyolali ). Naskah Publikasi. Fakultas Ekonomi Dan Bisnis Jurusan Akuntansi Universitas Muhammadiyah Surakarta

Trini Wulandari. 2013. Pengaruh Pengetahuan Dewan Tentang Anggaran Terhadap Pengawasan Keuangan Daerah Dengan Akuntabilitas Publik Sebagai Variabel Pemoderasi. Akuntansi FE UNP. WRA, Vol. 1, No. 2, Oktober 2013.

Undang-Undang Nomor 1 Tahun 2004 tentang Perbendaharaan Negara.

Undang-undang Nomor 32 Tahun 2004 tentang Pemerintah Daerah

Undang-undang Nomor 58 Tahun 2005 tentang Pengelolaan Keuangan Daerah

Waspada.co.id. 2017. Dewan upayakan perbaikan jalan lhoksukon cot-girek. http://waspada.co.id/aceh/dewan-upayakanperbaikan-jalan-lhoksukon-cot-girek/. (Dikunjungi pada 22/11/2017).

Wiwien widiyaastutie. 2008. Pengaruh Akuntabilitas Dan Transparansi Kebijakan Publik Terhadap Pengetahuan Dewan Tentang Anggaran Dengan Pengawasan Keuangan Daerah (Studi empiris pada DPRD Pemerintahan Jember). Fakultas Ekonomi Dan Bisnis Universitas Jember. 